\title{
People, not just places: Expanding social vulnerability indices by social-psychological factors
}

\author{
Philipp Babcicky ${ }^{1}$, Sebastian Seebauer ${ }^{1, a}$ \\ ${ }^{1}$ LIFE - Centre for Climate, Energy and Society, JOANNEUM RESEARCH Forschungsgesellschaft mbh, Graz, Austria
}

\begin{abstract}
Damage and disruption caused by floods do not just arise from the characteristics of physical structures, but also from the characteristics of residents inhabiting these structures. Social vulnerability studies typically employ sociodemographic proxy indicators that do not address the risk attitudes, beliefs and agency of those living in areas at risk. To close this gap, this paper introduces a range of indicators from psychological risk research. Physical, social and psychological indicators are compared for their influence on vulnerability outcomes such as building damage or emotional distress. Based on survey data of 456 Austrian at-risk households, hierarchical regression models confirm the additional explanatory value of psychological indicators above and beyond physical and social indicators. Adding psychological indicators up to doubles the explained variance in vulnerability outcomes, in particular for health impacts and distress. General intentions for flood preparedness, fear of flooding and self-efficacy are most relevant. For a more holistic view of vulnerability, measurement instruments should incorporate psychological indicators. Disaggregated household-level data is necessary to fully capture the inter-individual differences between households living in the same flood-prone area. Indicators perform differently depending on the other indicators included, and the considered outcome; therefore, we caution against pooling indicators to composite vulnerability indices.
\end{abstract}

\section{Introduction}

Vulnerability is "the propensity or predisposition to be adversely affected", denoted by the "susceptibility to harm and lack of capacity to cope and adapt" (IPCC 2014:5). Information on vulnerability to flood hazards is important for planning mitigation and preparedness measures and for prioritising projects if resources are limited (PapathomaKöhle et al. 2011; Birkmann 2006). The current risk management discourse is dominated by geosciences and engineering approaches which centre on physical vulnerability, that is the number of buildings, infrastructure, and cultural heritage exposed to floods (Birkmann et al. 2013; Jongman et al. 2014; Fuchs et al. 2017). In a similar vein, risk reduction schemes revolve around insurance and monetary compensation of damage (Prettenthaler et al. 2015). However, in her seminal work on social vulnerability, Susan Cutter and colleagues (Cutter et al. 2003) showed that not just the characteristics of physical structures, but also the characteristics of residents living in these structures play a major role for the extent of damage and disruption caused by natural disasters. A classic example for the divergence between physical and social vulnerability is the Vietnamese population in New Orleans during hurricane Katrina: Even though physically vulnerable due to poor housing conditions, their close-knit networks among families and neighbours helped them to better cope with the disaster (Leong et al. 2007).

Taking into account the capacities and needs of exposed residents, as Cutter suggests, requires valid indicators for capturing how well specific social groups prepare for, respond to and recover from flood events. For this purpose, social vulnerability studies typically rely on socio-demographic characteristics such as age, gender or income (e.g. Cutter et al. 2003). However, research on risk perception and preparedness behaviours has established a range of psychological factors that shape how residents deal with risk and consequently decrease or increase their vulnerability, such as fear, self-efficacy or social capital (Bubeck et al. 2012; van Valkengoed and Steg 2019; Kuhlicke et al. 2020). Therefore, social vulnerability assessments should not just accommodate sociodemographic proxy indicators readily available in census statistics, but should also address the motivations and beliefs of those living in areas at risk. Unfortunately, psychological indicators of vulnerability have not been taken into account as often as they might have been (Aerts et al. 2018; Saja et al. 2018; Tapsell et al. 2010).

The aim of the present paper is to widen the measurement scope of existing social vulnerability instruments by introducing a range of psychological vulnerability indicators. We show their added value by systematically comparing a spectrum of 43 physical, social and psychological indicators for their influence on seven vulnerability outcomes such as building damage or emotional distress. We draw on survey data of 456 residents living in twelve Austrian alpine municipalities at risk of pluvial or riverine flooding. A series of hierarchical regression models determines the unique effect of each vulnerability indicator, that is to say, the additional explanatory value of psychological indicators above and beyond traditional physical and social indicators. 
Therefore, the present paper offers a threefold contribution to the methodological debate on assessing vulnerability: First, we demonstrate how psychological factors, which are at times criticised for being vague and unclear, can be operationalised in a compact questionnaire format. Second, for the Austrian context, we show which specific psychological indicators are most relevant for painting a more comprehensive picture of household-level vulnerability to flood hazards. Our second contribution also leads us to caution against the common practice of pooling indicators into composite vulnerability indices, as our results indicate that the same indicators vary widely in their influence (in other words, their index weight) on different vulnerability outcomes. Third, in line with the social vulnerability perspective on people instead of places, we employ disaggregated household-level data. Most social vulnerability approaches based on the hazardof-place model (Cutter et al. 2003) use census statistics aggregated into geographical clusters or administrative districts. However, spatial and interpersonal aggregation obscures non-place-based individual differences between households living in the same hazard-prone area.

\section{Facets of vulnerability}

\subsection{Physical vulnerability}

Traditionally, hydrologists and engineers focus on the potential damage to an object resulting from its physical properties (Varnes 1984; Penning-Rowsell et al. 2005; Papathoma-Köhle et al. 2011). Physical vulnerability is quantified by damage curves which link potential damage to process characteristics. In flood vulnerability assessments, depth-damage-curves indicate the losses in assets or people that can be expected under a given inundation depth (Merz et al. 2010).

\subsubsection{Indicators of physical vulnerability}

Assessments of physical vulnerability address building-related factors. In the flood context, one such indicator is building type: The affected fraction of a multistorey building is typically smaller compared to a singlestorey building (Merz et al. 2010); however, multi-storey buildings can complicate evacuation when a large number of people are crowded in exit stairwells (Flanagan et al. 2011). A higher number of floors, the existence of a basement for instance, makes buildings more susceptible to flooding (Papathoma-Köhle et al. 2019; Solín et al. 2018). Building value and content, as well as size of the living area, indicate that expensive, well-furnished and large homes are more costly to repair (Kreibich et al. 2011; Apel et al. 2009). Whether a building is located in a risk zone (Jongman et al. 2014) indicates its exposure to flood hazards. Buildings in a remote location suffer from street connectivity which may impede timely evacuation (Saja et al. 2018) and make a reception of flood warnings less likely (as modeled in Kienberger 2012). The need to seek emergency shelter after flooding implies weak flood resistance of the building (Fekete 2009). Building ownership indicates less damage potential, as homeowners have more financial resources and more control over flood-proofing modifications than renters (Rufat et al. 2015; Cutter et al. 2003). Private preparedness measures are cost-effective in reducing flood damage at residential buildings (Kreibich et al. 2011). Finally, insurance helps to cover monetary losses; a lack of insurance can lead to more severe flood impacts (Lowe et al. 2013) and may postpone building reconstruction (Green et al. 2007).

\subsection{Social vulnerability}

In contrast to the building-related focus of physical vulnerability, social vulnerability addresses the individuals or households living in these buildings. Beyond susceptibility to flood hazards, social vulnerability highlights individual agency and capacity, i.e. personrelated characteristics which allow people "to anticipate, cope with, resist and recover from the impact of a natural hazard" (Wisner et al. 2004:11).

\subsubsection{Indicators of social vulnerability}

Socio-demographic characteristics such as age, gender and income are included in practically all social vulnerability indices (Werg et al. 2013). The elderly tend to be more fragile and financially weak (Morrow 1999), suffer from mobility constraints (Cutter et al. 2003), require more assistance during evacuation (Chakraborty et al. 2005), and need special medical equipment at shelters (McGuire et al. 2007). Children often lack resources, knowledge and life experiences to adequately respond to disasters (Flanagan et al. 2011). However, older people are more likely to hold insurance (Steinführer and Kuhlicke 2007), and have more disaster experience and anticipatory behaviour (Paul and Routray 2011). Likewise, children can be a protective factor, bridging community networks through schooling (Walker et al. 2012) and attracting support for their families (Kuhlicke et al. 2011). Household members with sensory, physical or mental disabilities, and those who require special care, are more vulnerable, as they are restricted in their own actions during and after a disaster (Jonkman 2007; Morrow 1999) and bind capacities of their caregivers or family members (Flanagan et al. 2011). Household size cuts both ways: In larger households, more people are affected which may lead to crowding in the case of evacuation (Flanagan et al. 2011). Conversely, larger households are endowed with more manpower and social networks both valuable in disaster situations (Velasquez and Tanhueco 2005).

The effect of gender on vulnerability remains contested (Rufat et al. 2015). On the one hand, women are considered more vulnerable, as they usually command fewer financial resources and often are primary caregivers with responsibilities that restrict them to immediately seek safety when a disaster strikes (Laska and Morrow 2007; Fothergill 1998). These negative effects may be offset by women demonstrating higher risk aversion (Salvati et al. 2018; Laska and Morrow 2007), more risk awareness and preparedness (Bateman and Edwards 2002), and a greater compliance with warnings and evacuations than men (Laska and Morrow 2007; Riad et al. 1999). 
Income is generally considered a protective factor, given that more affluent victims may absorb and recover from disaster impacts more swiftly (Cutter et al. 2003). Even though wealthy households own more assets, higher absolute losses still represent a lower relative proportion of their total financial means compared to poorer households (Flanagan et al. 2011). Moreover, low-income households are more vulnerable because they are more likely to live in highly exposed zones or low-quality housing (Laska and Morrow 2007; Mileti 1999), lack transportation for evacuation and struggle to afford the costs of reconstruction or relocation (Masozera et al. 2007; Gladwin and Peacock 1997). Income is a core social vulnerability indicator because of its correlation with other social indicators (Rufat et al. 2015), and because of its general role for mapping social stratification.

Education is considered another key determinant of social vulnerability, as limited knowledge and skills can restrict disaster resilience and evacuation behaviour (Lindell and Perry 2004; Morrow 1999), the understanding of warning information (Cutter et al. 2003) and the overcoming of practical and bureaucratic obstacles during disaster response and recovery (Morrow 1999). The attachment to a specific place - often measured by duration of residence - can stimulate householders to take precautionary measures in order to safeguard a place they value (Paton 2013). On the other hand, long-term residents may downplay in hindsight the damage they experienced in the past (Baker 1991). Newcomers may not be fully aware about the potential hazards that exist in the area (Seebauer and Winkler 2020). Households with access to cars can be considered less vulnerable, because private vehicles are crucial for timely evacuation (Sakakibara et al. 2004).

\subsection{Psychological vulnerability}

Even though social vulnerability assessments put the agency, resources and needs of those affected on centre stage, these assessments remain restricted to sociodemographic characteristics (Werg et al. 2013). Until to date, human perceptions and motivations have been left out of the equation (Aerts et al. 2018; Saja et al. 2018). This has sparked calls to develop more inclusive indicators (Doorn 2017) and to expand from mere personal characteristics towards the social relations people have within society (Tapsell et al. 2010). Psychological factors explain more variance in private flood protection behaviour than traditional socio-demographic factors (Grothmann and Reusswig 2006). Thus, the following section introduces a range of psychological vulnerability indicators, i.e. intra- and inter-personal motivations and beliefs that govern how people process threats and decide on flood-mitigative actions.

\subsubsection{Indicators of psychological vulnerability}

Risk perception, the combination of perceived probability and severity of a hazard event, is a wellestablished precursor of private flood mitigation (e.g. Kievik and Gutteling 2011; Grothmann and Reusswig 2006). Although the magnitude of this relationship is contested (Babcicky and Seebauer 2019a; Bubeck et al. 2012), households need to perceive a certain minimum level of risk in order to form intentions to take precautionary measures (Kievik and Gutteling 2011). Emotional risk appraisal, such as fear or worry of flooding, also influences preparedness behaviour (Terpstra 2011). Risk aversion, as a generally reserved attitude towards risk-taking, similarly influences household-level preparedness actions (Botzen et al. 2019; Jonkman and Kelman 2005).

Households do not engage in preparedness activities in an isolated sphere, but strive to comply with the normative expectations put forward by significant others (McIvor and Paton 2007). When households notice that others take flood precautionary measures, or start to evacuate, they are more likely to follow suit (Poussin et al. 2014; Lindell et al. 2005; Baker 1991). Expanding the social sphere from the close network to the local community points to social capital, which represents trust and support structures among the members of a specific community (Putnam et al. 1993). Social networks are key channels for early warning and evacuation messages (Rufat et al. 2015), facilitate collaboration in preparedness, response and recovery activities (Townshend et al. 2015), provide social and emotional support during disasters (Kaniasty and Norris 1995), and increase people's perceived abilities to take flood mitigative actions (Hudson et al. 2020). On the flipside, high levels of social capital may instil a false sense of safety and may hinder protective action (Babcicky and Seebauer 2017). Further expanding the social sphere to adaptive capacity building between civil society and formal institutions leads to a more institutional approach to social capital (Adger 2003). In flood risk management, institutional capital comprises administrative procedures for technical measures, emergency routines, support payments, and similar, and the presence of deliberative processes between authorities and civic actors (Thaler and Seebauer 2019).

Believing into being able to successfully take protective action lies at the roots of private adaptive capacity. This control belief appears at the individual, collective and political level. Self-efficacy, the confidence in one's own abilities, is among the strongest predictors of household (flood) preparedness (Botzen et al. 2019; van Valkengoed and Steg 2019). Collective efficacy, the joint belief of group members into their ability to achieve shared objectives, reflects how communities are able to solve hazard problems together and to deploy effective civic flood action (Babcicky and Seebauer 2019b). Political efficacy refers to a person's beliefs about being able to influence political processes, and about the responsiveness of authorities to citizens' concerns (Anderson 2010). Sidelining citizens in risk governance instead of involving them as participants and co-producers leads to inferior flood policy decisions (Tseng and Penning-Rowsell 2012) and insufficient allocation of public protection and recovery support to households in need (Remo et al. 2016; Pelling 1998).

Households may not always approach their flood risk in a pro-active manner, but may instead turn to nonprotective responses, which reduce negative emotions caused by a hazard, but do not protect households from 
potential physical harm (Bubeck et al. 2013). Wishful thinking inhibits flood-prone households from taking precautionary measures (Grothmann and Reusswig 2006). Reliance on public protection and reliance on public compensation divert flood-prone households from acting on risk as they count on receiving adequate external support when needed (Poussin et al. 2014; Terpstra 2011; Grothmann and Reusswig 2006). On a more general note, ascription of responsibility for flood mitigation to governmental actors makes households less aware about risks (Kuhlicke et al. 2011) and less likely to take actions themselves (Parker et al. 2009).

Several psychological factors pertain to coping with stressful situations in general (Connor and Davidson 2003; Friborg et al. 2005), which are also indicative for a person's resilience against flood hazards. Structured style reflects the ability to uphold daily routines, to plan and organize (Friborg et al. 2005); this characteristic was found to reduce the risk of anxiety and depression (Morote et al. 2017). Tolerance of negative affect refers to the "flexibility and promptness in coping with difficult situations and taking initiative to solve problems in a calm manner" (Fujikawa et al. 2013:214). The impact of spiritual influences on vulnerability can be two-sided: While faith-based social relations can provide emotional and practical support in disasters (Gianisa and Le De 2018), strong religious beliefs might cause inaction if hazard events are considered as an act of god (Misanya and Øyhus 2014).

\subsection{Vulnerability outcomes}

The vulnerability indicators introduced in the preceding sections 2.1 to 2.3 describe the exposure, susceptibility and coping capacities of households to flood risk, or, how people might be affected when a natural disaster occurs. By contrast, vulnerability outcomes refer to the manifest negative consequences households encounter during a disaster, when, as Tapsell et al. (2010) put it, underlying social vulnerabilities are revealed. In the present study, vulnerability indicators and vulnerability outcomes are conceptualised as a cause-effect relationship: Indicators are pre-existing conditions, and outcomes are the result of these conditions.

Vulnerability outcomes emerge in various ways during a flood; just as indicators should span physical, social and psychological facets, also outcomes should include physical (e.g. structural damage at one's home) as well as non-physical impacts (e.g. anxiety). In contrast to physical outcomes, non-physical outcomes have largely been neglected in vulnerability assessments and deserve considerably more attention (Brouwer and Schaafsma 2013). A vulnerability indicator may predict some outcomes better than others. It is therefore essential to consider a broad range of different outcomes that floods can produce.

Physical outcomes include damage to buildings and their contents (Kind et al. 2019; Karagiorgos et al. 2016) and the loss of irreplaceable personal items and memorabilia (Penning-Rowsell and Green 2000). While physical outcomes are usually quantified in monetary terms, non-physical outcomes are more difficult to measure and include, for example, being forced to leave one's home and seek emergency shelter (Fekete 2019) or when they experience post-flood stress with insurance claims and restoration of damaged homes (Tapsell et al. 2010). Flood victims may face health impacts, including injury, illness or death, but also mental impacts, such as post-traumatic stress disorder, anxiety, sleeping problems, or may struggle with an exhausting and prolonged process of getting back to normal life (Walker-Springett et al. 2017; Karagiorgos et al. 2016; Wedawatta et al. 2014; Mason et al. 2010).

\section{Method}

\subsection{Study setting and data collection}

Between December 2019 and February 2020, a household survey was conducted in five municipalities of the Ennstal district and seven municipalities of the Freistadt district in Austria. These regions were selected for their high risk of flooding and the recent occurrence of severe floodings (Hübl and Beck 2018; Habersack et al. 2005). In Ennstal and in four of the Freistadt municipalities, standardised self-completion questionnaires were distributed as inserts in municipal newspapers. In the remaining three Freistadt municipalities, as only few at-risk households live there, residential areas located in or nearby flood risk zones were geo-targeted by direct mailing. Respondents were instructed to return questionnaires in a prepaid envelope or drop them off at local municipal offices. In parallel, an identical online survey was promoted via the municipalities' online channels, local associations (e.g. fire brigade) and in sponsored articles on social media. Redeemable vouchers and small gift donations (sponsored by the municipalities) were used as survey incentives. Municipal newspapers and direct mailing were distributed to all households living in the surveyed areas; therefore, this method allowed us to reach almost the entire local population.

Overall, 1,077 valid questionnaires were returned, which corresponds to a response rate of $9.3 \%$. However, listwise deletion of missing values reduces the sample for analysis to 456 households, since hierarchical regression analysis requires complete information on all indicators and outcomes for each household. The households are fairly equally distributed across municipalities (2.4 to $16.2 \%$ ), with a larger share contributed by more populated municipalities (Table A1). The distribution of sociodemographics in the sample is largely in line with census data, except for an overrepresentation of male respondents. About $28 \%$ of the households stated that they had already experienced a flood event in the past, and $19 \%$ reported to live in a flood risk zone.

\subsection{Measures}

The survey contained thirteen physical, eleven social and nineteen psychological vulnerability indicators, as well as seven vulnerability outcomes; the preceding sections 2.1 to 2.4 review these indicators and outcomes. 
The majority of physical and social indicators was measured by single items. Where feasible, psychological indicators were measured on multi-item scales to correct for measurement error. Items were presented in the questionnaire in mixed order to avoid artificial inflation of intra-scale correlations (Podsakoff et al. 2003). Detailed item wordings and scale reliabilities are given in Table A2 in the Appendix.

Physical vulnerability indicators included building type (detached house vs. multi-storey building), presence and use of a basement and ground floor, building and content value, and size of living area. Households indicated the remoteness of their building and whether their property is located in a flood risk zone. Households were asked whether they had already experienced a flood event at their property. Further indicators in this category comprised the perceived likelihood of receiving early warnings, the availability of external shelter in case of a flood emergency, status as homeowner or tenant, and whether households had taken any flood protective actions or purchased insurance.

Social vulnerability indicators included a breakdown of household composition, including the number of household members with disabilities, the number of infants ( $<3$ years), children ( 3 to 13 years), elderly ( $>60$ years) and the total household size. Further sociodemographic characteristics included gender, income and level of education, as well as duration of residence and car access.

Psychological vulnerability indicators included perceived flood probability (single item, Grothmann and Reusswig 2006), intentions to take flood precautionary measures ( $\alpha=.80$, three items), fear of flooding ( $\alpha=.79$, two items, Terpstra 2011), risk-taking (single item, Bierlein et al. 2014), social norms ( $\alpha=.66$, three items, Babcicky and Seebauer under review), social and institutional capital $(\alpha=79, \alpha=.83$, four items each, Babcicky and Seebauer 2017; Thaler and Seebauer 2019), and self-efficacy ( $\alpha=60$, three items, Babcicky and Seebauer 2019b). Collective efficacy distinguished between external collective efficacy, which describes the belief that community goals can be achieved through collective action ( $\alpha=.67$, three items, Babcicky and Seebauer 2019b), and internal collective efficacy, which reflects the belief that a person's participation is effective to achieve community goals ( $\alpha=.66$, three items, van Zomeren et al. 2013). A similar distinction was drawn between internal and external political efficacy: Internal political efficacy captures the belief that one can understand and effectively participate in politics, whereas external political efficacy measures how responsive government is perceived with regards to citizens' demands $(\alpha=55, \alpha=.69$, two items each, Bierlein et al. 2012). Measures for non-protective responses included wishful thinking $(\alpha=.47$, two items, Seebauer and Babcicky 2018), reliance on public flood protection ( $\alpha=83$, three items, Bubeck et al. 2017; Terpstra 2011) and reliance on public compensation ( $\alpha=.72$, three items, Botzen et al. 2019), and ascription of responsibility between private and governmental actors (single-item, Botzen et al. 2009). Three forms of intrapersonal resilience when coping with adverse events were assessed: Structured style $(\alpha=.53$, two items, Friborg et al.
2005), tolerance of negative affect, and spiritual influences $(\alpha=.54, \alpha=.39$, two items each, Connor and Davidson 2003).

Vulnerability outcomes were assessed by presenting respondents a hypothetical flood situation with ankle-high flooding at their home (ground floor and basement, if present, are affected). Respondents stated how severely they would expect seven different physical and nonphysical types of damage, ranging from immediate to longer-lasting effects. Physical outcomes included damage at building and contents, loss of personal items and financial damage. Non-physical outcomes comprised health impacts (e.g. fatigue, injuries), stress (e.g. moving assets out of harm's way, tiresome clean-up operations), mental impacts (e.g. sleeping disorder, helplessness) and struggle to return to normal (e.g. tedious reconstruction, bureaucratic hurdles).

\subsection{Analytical approach}

A series of hierarchical regression analyses identifies the determinants of different vulnerability outcomes and compares the explanatory power of physical, social and psychological indicators. Vulnerability indicators enter the models as predictors in four blocks: Block 1, traditional physical indicators; block 2, traditional social indicators. As perceived flood probability and perceived consequences (here: vulnerability outcomes) are both components of risk perception, perceived flood probability is expected to be more closely correlated with vulnerability outcomes than other psychological indicators. Therefore, perceived flood probability enters the regressions separately in block 3 in order to avoid obscuring the additional value of the other psychological indicators. The remaining psychological indicators are added in block four. Regression results are presented in Table 1. Variance inflation factors (VIF) for the full models do not exceed 3.5 , indicating no issues of multicollinearity among the predictors (Kennedy 2003).

The next section 4.1 assesses the added value of social and psychological indicators by comparing how the total variance explained $\left(\mathrm{R}^{2}\right)$ in each of the seven vulnerability outcomes increases when stepwise adding the four indicator blocks. In sections 4.2 to 4.4 , we then discuss indicators that are statistically significant in the full fourblock models. The regression coefficients of these indicators give their unique effect while controlling for the entire range of all other vulnerability indicators. 
Table 1. Hierarchical regression results for physical, social and psychological vulnerability indicators

\begin{tabular}{|c|c|c|c|c|c|c|c|c|c|c|c|c|c|c|c|c|c|c|c|c|c|c|c|c|c|c|c|c|}
\hline \multirow[b]{2}{*}{ Physical indicators } & \multicolumn{4}{|c|}{ Building \& contents damage } & \multicolumn{4}{|c|}{ Loss of personal items } & \multicolumn{4}{|c|}{ Financial damage } & \multicolumn{4}{|c|}{ Health impacts } & \multicolumn{4}{|c|}{ Stress } & \multicolumn{4}{|c|}{ Mental impacts } & \multicolumn{4}{|c|}{ Struggle to return to normal } \\
\hline & Phys (1). & Soci (2) & FIPr (3) & Psyc (4) & Phys (1) & Soci (2) & FIPr (3) & $\overline{P s y c}(4)$ & Phys (1) & Soci (2) & $F \operatorname{PPr}(3)$ & Psyc (4) & Phys (1) & Soci(2) & FIPr (3) & Psyc (4) & $\overline{\text { Phys (1) }}$ & Soci (2) & FIPr (3) & $\overline{P_{\text {syc }}(4)}$ & $\overline{P h y s(1)}$ & Soci (2) & FIPr (3) & $P_{S y y c}^{(4)}$ & Phys (1) & Soci (2) & FIPr (3) & $P_{\text {syc (4) }}$ \\
\hline Building type (house/apartment) & -.03 & -.05 & -.07 & -.08 & .06 & .04 & .02 & .01 & .05 & -.08 & -.1 & $-.12^{*}$ & -.12 & $-.12^{*}$ & $-14^{* *}$ & $-18^{* * *}$ & -.04 & -.06 & -.08 & -10 & $-.16^{* *}$ & $-.17^{* *}$ & $-19^{* * *}$ & $-.22^{* * * *}$ & $-.12^{*}$ & $-.13^{* *}$ & $-.15^{* *}$ & $-16^{* *}$ \\
\hline Basement (no/yes) & .03 & .06 & .07 & .07 & .00 & .03 & .04 & .04 & -.03 & -.01 & -.01 & .00 & .00 & .02 & .02 & .04 & -.02 & .00 & .01 & .03 & -.01 & .00 & .01 & .03 & .00 & .01 & .01 & .03 \\
\hline Ground floor (no/yes) & $.17 * * *$ & $.15 * * *$ & $.15^{* * *}$ & $.15 * * *$ & $.19^{* * *}$ & $.18^{* * *}$ & $.18^{* * *}$ & $.17^{* * *}$ & $.17^{* * *}$ & $.16^{* * *}$ & $.17 * * *$ & $.15 * * *$ & $.11^{* *}$ & $.11^{* *}$ & $.11^{* *}$ & $.10^{*}$ & $.15^{* * *}$ & $.13^{* *}$ & $.14^{* * *}$ & $.13^{* * *}$ & .05 & .05 & .06 & .05 & .05 & .05 & .05 & .05 \\
\hline Building and contents value & .01 & .01 & .01 & .02 & .00 & .01 & .01 & .01 & $-.09 *$ & -.06 & -.06 & -.05 & -.06 & -.04 & -.05 & -.04 & -.05 & -.04 & -.04 & -.02 & -.07 & -.04 & -.04 & -.02 & -.05 & -.01 & -.01 & .01 \\
\hline Size of living area & -.06 & -.08 & -.07 & -.07 & -.07 & -.09 & -.08 & -.08 & .02 & .03 & .03 & .03 & .02 & .01 & .02 & .02 & .02 & -.01 & .00 & .00 & -.02 & -.02 & -.02 & -.01 & -.05 & -.04 & -.04 & -.03 \\
\hline Location (remote/central) & $.08^{*}$ & $.10^{* *}$ & $.08^{*}$ & .07 & $.11^{* *}$ & $.14^{* * *}$ & $.13 * * *$ & $.11^{* *}$ & .07 & .07 & .05 & .03 & $.14^{* * *}$ & $.15 * * *$ & $.14^{* * *}$ & $.10^{* *}$ & $.09^{*}$ & $.11^{* *}$ & $.09 *$ & $.08^{*}$ & $.10^{* *}$ & $.11^{* *}$ & $.09 * *$ & .07 & $.10^{* *}$ & $.10^{* *}$ & $.08^{*}$ & .06 \\
\hline Risk zone (no/yes) & $.18^{* * *}$ & $.16 * * *$ & .02 & .01 & .06 & .04 & -.05 & -.07 & $.19^{* * *}$ & $.14^{* * *}$ & .03 & .00 & $.12^{* *}$ & $.09 *$ & -.02 & -.07 & $.12^{* *}$ & $.08^{*}$ & -.03 & -.08 & $.14^{* * *}$ & $.10^{* *}$ & -.01 & -.06 & $.15^{* * *}$ & $.11^{* *}$ & .02 & -.02 \\
\hline Flood experience (no/yes) & .06 & $.08^{*}$ & .04 & .05 & .03 & .05 & .02 & .03 & -.06 & -.04 & -.07 & -.06 & .00 & .02 & -.02 & .00 & .04 & .07 & .04 & .04 & .04 & -.02 & -.05 & -.03 & -.07 & -.05 & $-.08^{*}$ & -.07 \\
\hline Timely early warning & .02 & .03 & .03 & .03 & .04 & .05 & .05 & .05 & .03 & .03 & .03 & .03 & .04 & .05 & .05 & .03 & .07 & $.08^{*}$ & $.09 * *$ & $.09^{* *}$ & .03 & .03 & .04 & .04 & $.08^{*}$ & $.09^{* *}$ & $.10^{* *}$ & $.08^{*}$ \\
\hline External shelter availability & .02 & -.02 & .00 & .00 & -.06 & $-.08^{*}$ & -.07 & -.06 & -.05 & -.07 & -.06 & -.04 & $-14^{* * * *}$ & $-.15^{* * *}$ & $-.14^{* * *}$ & $-.12^{* * *}$ & -.06 & $-.10^{* *}$ & $-.09 * *$ & $.09 * *$ & $-.12^{* *}$ & $-.12^{* * *}$ & $-.11^{* *}$ & $-.08^{*}$ & $-.16^{* * *}$ & $-.16^{* * *}$ & $-.15 * * *$ & $-.12^{* * *}$ \\
\hline Building ownership (no/yes) & .00 & .07 & .08 & .08 & .00 & .07 & .07 & .08 & .02 & .09 & .09 & .09 & -10 & -.03 & -.02 & -.03 & -.06 & .03 & .03 & .03 & -.07 & -.01 & .00 & .00 & .02 & .07 & .08 & .07 \\
\hline Flood protective measures & .03 & .05 & -.03 & .01 & .03 & .05 & .00 & -.01 & .06 & .08 & .02 & .06 & .07 & .09* & .03 & .07 & .05 & .07 & .01 & .09 & $.09^{*}$ & $.10^{* *}$ & .04 & $.12^{*}$ & . $09^{*}$ & $.10^{* *}$ & .05 & .07 \\
\hline $\begin{array}{l}\text { Insurance (no/yes) } \\
\text { (n) }\end{array}$ & $.11^{* *}$ & $.11^{* *}$ & $.10^{* *}$ & $.09 * *$ & .06 & .07 & .06 & .07 & .06 & .07 & .06 & $.10^{* *}$ & -.05 & -.05 & -.07 & -.08 & .00 & .00 & -.02 & .00 & .03 & .05 & .03 & .06 & .00 & .02 & .00 & .03 \\
\hline \multicolumn{29}{|l|}{ Social indicators } \\
\hline & & $-.14^{* *}$ & $-.13^{* *}$ & $-.15^{* *}$ & & -.08 & -.07 & -.05 & & -.05 & .05 & -.08 & & .03 & .04 & .02 & & -.06 & -.05 & $-.12^{*}$ & & .05 & .06 & .04 & & .07 & .07 & .06 \\
\hline$\#$ of $\mathrm{hh}$ members w/ disabilities & & -.06 & $-.07 *$ & -.06 & & -.04 & -.05 & -.04 & & .01 & .00 & .02 & & -.01 & -.02 & .00 & & .04 & -.05 & -.01 & & -.03 & -.04 & .01 & & -.04 & -.05 & -.01 \\
\hline$\#$ of very young children (<3y.) & & .02 & .05 & .06 & & -.04 & -.02 & -.04 & & .03 & .05 & .04 & & $-.10^{*}$ & -.07 & $-.08 *$ & & .03 & -.01 & -.02 & & -.05 & -.03 & -.03 & & -.04 & -.02 & -.02 \\
\hline$\#$ of children (3 to $13 \mathrm{y}$.) & & .03 & .05 & .04 & & .01 & .02 & .03 & & .05 & .06 & .06 & & .00 & .01 & .00 & & -.01 & .01 & .01 & & -.01 & .01 & .02 & & -.04 & -.03 & -.01 \\
\hline$\#$ of elderly hh members (> $60 \mathrm{y}$.) & & -.06 & -.07 & -.06 & & -.05 & -.05 & -.06 & & $-.13 * *$ & $-.13 * *$ & $-.13^{* *}$ & & -.09 & $-.10^{*}$ & $-.11^{*}$ & & $-.13^{* *}$ & $-.14^{* *}$ & $-.13^{* *}$ & & -.09 & $-.10^{*}$ & -.09 & & -.09 & -.09 & -.09 \\
\hline$\#$ of hh members (total) & & .01 & .00 & .00 & & .08 & .07 & .07 & & .05 & .04 & .04 & & .04 & .03 & .02 & & .07 & .06 & .03 & & .09 & .08 & .05 & & .13 & .12 & .09 \\
\hline Gender $(\mathrm{f} / \mathrm{m})$ & & $-.09 * *$ & $-.08^{*}$ & -.08 & & $-.17 * * *$ & $-.16^{* * *}$ & $-.13^{* *}$ & & $-.21 * * *$ & $-2^{* * *}$ & $-.18 * * *$ & & $-.22^{* * *}$ & $-.21^{* * *}$ & $-.21^{* * *}$ & & $-.19^{* * *}$ & $-.18^{* * *}$ & $-.18^{* * *}$ & & $-.28^{* * *}$ & $-.27 * *$ & $-.24 * * *$ & & $-.25 * * *$ & $-.24^{* * *}$ & $-.19 * * *$ \\
\hline Household income & & -.05 & -.03 & -.02 & & $-.11^{*}$ & $-10^{*}$ & -.05 & & $-.12^{* *}$ & $-10^{* *}$ & -.07 & & -.08 & -.06 & -.04 & & -.05 & -.04 & -.02 & & $-.12^{* *}$ & $-.11^{* *}$ & -.04 & & $-.13^{* *}$ & $-.12^{* *}$ & -.04 \\
\hline Education & & .03 & .05 & .04 & & .00 & .01 & .02 & & -.03 & -.02 & -.02 & & -.02 & -.01 & -.02 & & .03 & .04 & .02 & & .02 & .04 & .03 & & -.04 & -.03 & -.03 \\
\hline Length of residence & & -.07 & -.05 & -.05 & & -.10 & -.09 & -.09 & & .03 & -.02 & -.01 & & -.10 & -.08 & -.09 & & -10 & -.08 & -.09 & & -.07 & -.05 & -.07 & & $-.11^{*}$ & -.09 & $-.11^{*}$ \\
\hline \# of vehicles & & -.01 & .00 & .00 & & .01 & .01 & .00 & & -.08 & -.07 & -.08 & & .04 & .05 & .06 & & -.01 & .00 & .01 & & -.01 & .00 & .00 & & -.03 & -.02 & -.02 \\
\hline \multicolumn{29}{|l|}{ Psychological indicators 1} \\
\hline \\
\hline Protection intention & & & & -.06 & & & & -.09 & & & & -.09 & & & & $-.12^{*}$ & & & & $-.12^{*}$ & & & & $-17^{* * * *}$ & & & & $-.12^{*}$ \\
\hline Fear of flooding & & & & .03 & & & & $.12^{*}$ & & & & .09 & & & & $.23^{* * *}$ & & & & $.20^{* * *}$ & & & & $.23^{* * *}$ & & & & $.24 * * *$ \\
\hline Risk-taking & & & & -.07 & & & & .04 & & & & -.03 & & & & -.06 & & & & $-.09^{*}$ & & & & -.07 & & & & $-.10^{* *}$ \\
\hline Social norms & & & & .02 & & & & .09 & & & & .05 & & & & .02 & & & & -.01 & & & & -.01 & & & & .04 \\
\hline Social & & & & -.08 & & & & .01 & & & & .02 & & & & -.05 & & & & -.03 & & & & -.05 & & & & -.09 \\
\hline Institutional capital & & & & .03 & & & & .00 & & & & -.06 & & & & -.03 & & & & -.03 & & & & -.06 & & & & -.01 \\
\hline Self-efficacy & & & & -.06 & & & & -.01 & & & & $-.11^{*}$ & & & & $-.13^{* *}$ & & & & $-.11^{*}$ & & & & -.09 & & & & -.08 \\
\hline Collective efficacy: internal & & & & -.02 & & & & .04 & & & & .05 & & & & .03 & & & & -.06 & & & & .02 & & & & .03 \\
\hline acy: external & & & & .05 & & & & .02 & & & & .07 & & & & .07 & & & & $.10^{*}$ & & & & $.13^{* *}$ & & & & .10 \\
\hline Political efficacy: internal & & & & -.01 & & & & -.09 & & & & -.04 & & & & .02 & & & & -.01 & & & & -.07 & & & & -.05 \\
\hline Political efficacy: external & & & & .04 & & & & -.04 & & & & .02 & & & & .09 & & & & $.20^{* * *}$ & & & & .07 & & & & .00 \\
\hline Wishful thinking & & & & -.04 & & & & -.05 & & & & .01 & & & & -.02 & & & & -.02 & & & & -.02 & & & & -.03 \\
\hline lood protection & & & & -.05 & & & & .03 & & & & -.02 & & & & -.03 & & & & $-.12^{* *}$ & & & & -.05 & & & & -.01 \\
\hline Trust i & & & & .01 & & & & -.04 & & & & $-.10^{* *}$ & & & & .08 & & & & .00 & & & & -.05 & & & & -.05 \\
\hline Perceived responsibil & & & & -.01 & & & & -.03 & & & & $-.10^{* *}$ & & & & $-.08 *$ & & & & -.07 & & & & $-.08^{*}$ & & & & -.07 \\
\hline Structured $\mathrm{s}$ & & & & -.05 & & & & .04 & & & & -.03 & & & & -.07 & & & & -.04 & & & & -.02 & & & & -.04 \\
\hline Tolerance of negative feelings & & & & $\begin{array}{l}.08 \\
.00\end{array}$ & & & & $\begin{array}{r}-.08 \\
.04\end{array}$ & & & & .02 & & & & .01 & & & & -.02 & & & & $-.09^{*}$ & & & & $-.08^{*}$ \\
\hline $\begin{array}{l}\text { Spiritual influences } \\
R^{2} \text { adj. }\end{array}$ & .09 & .15 & .24 & $\begin{array}{l}.00 \\
.23\end{array}$ & .03 & .09 & .13 & $\begin{array}{l}.04 \\
.13\end{array}$ & .08 & .17 & .23 & $\begin{array}{l}.03 \\
.24\end{array}$ & .06 & .12 & .17 & .06 & $\begin{array}{l}.04 \\
\end{array}$ & 13 & .19 & $\begin{array}{l}.01 \\
.26\end{array}$ & $\begin{array}{l}0.05 \\
\end{array}$ & .14 & .20 & $\begin{array}{l}.04 \\
.27\end{array}$ & .07 & .14 & .18 & . .07 \\
\hline$\Delta F$ & $4.33^{* * *}$ & $3.9^{* * *}$ & $5.9^{* * *}$ & 0.7 & $2.1^{* * *}$ & $3.8^{* * *}$ & $18.6^{* * *}$ & 0.10 & $3.9 * * *$ & $5.7^{* * *}$ & $3.5^{* * *}$ & $1.5^{*}$ & $3.2^{* * *}$ & $3.6^{* * *}=$ & $31.6^{* * *}$ & $2.6^{* * *}$ & $2.55^{* * *}$ & $5.3^{* * *}$ & $31.9^{* * *}$ & $3.3^{* * *}$ & $2.9^{* * *}$ & $5.1^{* * *}$ & $\begin{array}{l}31.8^{* * *} \\
5.6\end{array}$ & $3.6^{* * *}$ & $3.5^{* * *}$ & $4.5^{* * *}$ & $21.3^{* * *}$ & $3.2^{* * * *}$ \\
\hline
\end{tabular}




\section{Results}

\subsection{Explanatory power of physical, social and psychological indicators}

Physical indicators alone explain between 3 to $9 \%$ of the variance in vulnerability outcomes. The explanatory power of physical indicators is highest for building and contents damage, suggesting that physical indicators are especially relevant for structural impacts of floods. Adding social indicators significantly raises explained variance up to 9 to $17 \%$. When combined, physical and social indicators perform best in explaining financial impacts $\left(\mathrm{R}^{2}=.17\right)$. The increase in explanatory power by adding social indicators is highest regarding financial damage, stress and mental impacts, each with an increase in explained variance by $9 \%$.

Adding perceived flood probability brings the explained variance in vulnerability outcomes up to 13 to $24 \%$, signifying another statistically significant improvement in model fit. Upon adding the remaining psychological indicators, explained variance increases again, most pronounced for the non-physical vulnerability outcomes health impacts, stress, mental impacts, and struggle to return to normal, reaching a total explained variance of up to $27 \%$. Overall, psychological indicators (including perceived flood probability) account for an additional 4 to $13 \%$ of the variance in vulnerability outcomes, up to doubling the explanatory power of common physical and social vulnerability indicators. However, psychological indicators (apart from perceived flood probability) seem to be less important for physical outcomes, as apparent in the models on building and contents damage, loss of personal items, and financial damage.

Overall, entering vulnerability indicators in separate blocks, shows that each facet of vulnerability has particular strengths and that solely focusing on physical indicators would yield an incomplete picture. Our results replicate the established relevance of social vulnerability indicators, but provide empirical evidence for the legitimacy, if not necessity, of psychological indicators. The increases in explanatory power suggest that vulnerability needs to be understood (and measured) as a multi-faceted concept, integrating both physical, social and psychological characteristics.

\subsection{Effects of physical vulnerability indicators}

The physical indicator with the most consistent effect across outcomes is ground floor ( $\beta=.10$ to .17 ), showing that households living at ground level expect higher flood impacts than those in higher storeys (except for mental impacts and return to normal). This coincides with the finding that households living in multi-storey buildings anticipate less financial, health and mental impacts compared to detached houses ( $\beta=-.12$ to -.22$)$. Households who have access to external shelters expect lower flood impacts ( $\beta=-.08$ to -.12 ), except for building and contents damage, loss of personal items and financial damage.
Households in more central, less remote locations perceive themselves as more vulnerable regarding loss of personal items $(\beta=.11)$, health impacts $(\beta=.10)$ and stress $(\beta=.08)$. Those who expect to receive early warnings, anticipate more stress $(\beta=.09)$ and a more tedious return to normal $(\beta=.08)$. Perhaps, these households believe that early warnings are only released in case of potentially disastrous flooding, leading to more severe impacts. Insurance is related to higher building and contents damage $(\beta=.09)$ and financial impacts $(\beta=.10)$, presumably because insurance policies are taken out to mitigate these very impacts. Also, the existence of protective measures is positively associated with mental impacts $(\beta=.12)$. It seems that the protective quality provided by flood-proofing does not extend to the mental and remains limited to the structural.

A range of physical indicators do not turn out statistically significant in any of the models, including basement, building and contents value, size of the living area, risk zone, flood experience and homeownership. The lack of significance suggests that the unique effect of these indicators is marginal compared to the importance of other, statistically significant indicators.

\subsection{Effects of social vulnerability indicators}

Social vulnerability indicators generally emerge as buffering factors that attenuate potential disaster impacts. Gender influences six out of seven vulnerability outcomes ( $\beta=-.13$ to -.24 ), in terms of male residents expecting significantly less impacts from a flood event. Older age leads to fewer building and contents damage $(\beta=-.15)$ and less stress $(\beta=-.12)$. The presence of elderly household members implies less negative consequences in terms of financial $(\beta=-.13)$, health $(\beta=-.11)$ and stress impacts $(\beta=-$ $.13)$. Households with very young children anticipate lower health impacts $(\beta=-.08)$. Residing in the area already for a longer period, makes households expect a less tedious return to normal $(\beta=-.11)$.

No significant effects are observed for the presence of household members with disabilities, the presence of children, household size, income, education and car access.

\subsection{Effects of psychological vulnerability indicators}

As expected, perceived flood probability is positively related with all vulnerability outcomes, apart from return to normal ( $\beta=.14$ to .32 ), indicating that the higher households judge the probability of a flood event, the more damage they anticipate. This resonates with the conceptual understanding of risk as the combination of perceived probability and severity (Grothmann and Reusswig 2006). In a similar vein, fear of flooding leads to more severe outcomes regarding loss of personal items $(\beta=.12)$, health $(\beta=.23)$, stress $(\beta=.20)$, mental impacts $(\beta=.23)$ and return to normal $(\beta=.24)$. By contrast, a general attitude towards taking risks implies lower levels of stress $(\beta=-.09)$ and a less tedious return to normal $(\beta=-.10)$.

Households who intend to take flood-protective measures, anticipate less impacts regarding health $(\beta=-$ $.12)$, stress $(\beta=-.12)$, mental health $(\beta=-.17)$ and return to 
normal $(\beta=-.12)$. Those who believe in their own ability to take protective actions, i.e. those with higher self-efficacy, expect lower financial $(\beta=-.11)$, health $(\beta=-.13)$ and stress impacts $(\beta=-.11)$. Stronger belief in external collective efficacy is associated with more stress $(\beta=.10)$ and mental impacts $(\beta=.13)$; perhaps, a flood event so severe that it requires collective action, is also perceived as considerably more stressful and mentally demanding.

If citizens believe that the local government is responsive to their concerns (i.e. high external political efficacy), they anticipate more stress during a flood event $(\beta=.20)$. Possibly, these households think that their political representatives only lend them their ear because of a more-than-usual threat. Other indicators point to a reassuring function of the authorities: Those who rely on public flood protection expect less stress during flooding $(\beta=-.12)$ and those who rely on public compensation expect fewer financial impacts $(\beta=-.10)$. The more households consider flood protection a private - as opposed to a public - responsibility, the less severe financial damage $(\beta=-.10)$, fewer health $(\beta=-.08)$ and mental impacts $(\beta=-.08)$ they expect. Finally, households who describe themselves as being able to tolerate negative affect, anticipate fewer mental impacts $(\beta=-.09)$ and a smoother return to normal $(\beta=-.08)$.

Overall, the majority of psychological indicators yield significant effects in the seven full models, particularly regarding person-related non-physical outcomes (e.g. stress, health and mental impacts), rather than regarding building-related physical outcomes (e.g. building and contents damage). These results suggest that psychological indicators merit better integration in vulnerability assessments.

\section{Discussion and conclusions}

Assessing the vulnerability of private households to flood hazards should take a wide scope of physical, social and psychological facets into account. Social vulnerability research has established that the needs and capacities of people exposed to risk shape how they are affected by natural disasters. The present study argues that the measurement of vulnerability should go beyond sociodemographic characteristics and should incorporate psychological indicators capturing risk attitudes, beliefs and agency of households living in areas at risk. In our Austrian survey sample, adding psychological indicators up to doubles the explanatory power of common physical and social vulnerability indicators, in particular with regards to health and mental impacts. From a range of psychological indicators, general intentions to take flood precautionary measures, fear of flooding and self-efficacy turn out most relevant. However, expanding the existing vulnerability instruments by psychological indicators raises two fundamental methodological implications for improving current measurement approaches: Employing household-level data, and scrutinising the usage of composite vulnerability indices.

As vulnerability is linked to the needs and capacities of individuals, it needs to be measured at the household level. Traditional social vulnerability approaches employ geographical regions as unit of analysis and sum up all households living in the same country, district or community (Tonmoy et al. 2014). However, households living in the same region may be highly diverse (Fekete 2012); or, if households are grouped by similar vulnerability, these groups may not necessarily cluster spatially (Doorn 2017). The higher the level of spatial aggregation, the higher the risk of levelling out interindividual differences and failing to account for constitutive factors of individual vulnerability (O'Brien et al. 2004). Often, spatial aggregation arises from necessity: Vulnerability assessments might have to accept less granular but readily available census data because these assessments cannot engage in the extra effort of conducting a dedicated household survey (Solín et al. 2018; Tonmoy and El-Zein 2018). Our results clearly suggest that it is worthwhile to conduct household vulnerability surveys. However, household self-responses in surveys are inherently coloured by subjective perceptions. While psychological indicators are subjective by nature, physical indicators such as risk zone or floodproofing of the building fabric may be biased if elicited from respondents who lack hazard and technical literacy. Thus, measuring the full scope of physical, social and psychological indicators at the household level might require to complement standardised questionnaires with time- and cost-intensive on-site expert assessments.

As vulnerability is multi-faceted, adding up indicators to a composite index can only deliver an oversimplified picture. Our results show that indicators perform differently depending on the other indicators included, and the considered vulnerability outcome. Lumping together indicators and outcomes into a single score most likely obscures the details essential for effective risk management providing, for instance, targeted support to disadvantaged groups. If a total vulnerability index is nevertheless deemed necessary, decisions need to be made regarding how much each indicator contributes to the total index. Weighting procedures are often missing in empirical studies or follow a simplicity rationale (Tonmoy and El-Zein 2018; Rufat et al. 2015). For a lack of appropriate alternatives, several indices plainly use equal weighting (Tate 2012; Gan et al. 2017). Collating expert judgments in participatory methods carries high subjectivity (Samira et al. 2019; Papathoma-Köhle et al. 2019). Weighting by factor loadings in principal component analysis only reflects how well the respective indicators fit under a common conceptual umbrella, but not how much they ultimately contribute to vulnerability outcomes (Gan et al. 2017). Instead, regression coefficients, as calculated in our study, may inform more realistic weights since they directly state an indicator's influence on the magnitude of a particular impact.

However, regression coefficients presume a causal direction from vulnerability indicator to vulnerability outcome which cannot be ensured by cross-sectional data such as used in the present study. For instance, higher selfefficacy may lead to lower expected impacts on finances, health and wellbeing, as assumed in our models; however, the inverse might as well apply, as expecting weaker impacts may give rise to beliefs of being able to tackle these impacts. Longitudinal studies would be necessary to 
confirm causal directions, ideally by collecting pre- and post-flood data. A further limitation of this study lies in using a rating scale for self-reported expected impacts as vulnerability outcomes. The endpoints of the rating scale refer to each respondent's subjective understanding of what amounts to a very weak or very severe impact instead of being anchored to objective values that uniformly apply across all respondents; similarly, the scale steps are dimensionless and do not translate into a uniform metric. Thus, we advise to interpret the outcome scale only for correlations and relative comparisons, but not for mean levels and absolute comparisons. We would welcome future studies to validate our findings using experienced impacts, or using monetary damage and health diagnostics of outcome measurements that can be generalised across households or regions. Still, subjective ratings seem indispensable for including non-physical vulnerability outcomes, such as emotional distress or personal burden.

\section{Acknowledgments}

This research was funded by the Austrian Climate and Energy Fund and was carried out within the Austrian Climate Research Program (project number B769942).

\section{References}

Aerts, J. C., Botzen, W. J., Clarke, K. C., Cutter, S. L., Hall, J. W., Merz, B., Michel-Kerjan, E., Mysiak, J., Surminski, S., Kunreuther, H. (2018). Integrating human behaviour dynamics into flood disaster risk assessment. Nature Climate Change, 8(3), 193-199.

Anderson, M. R. (2010). Community psychology, political efficacy, and trust. Political Psychology, 31(1), 59-84.

Adger, V. N. (2003). Social capital, collective action, and adaptation to climate change. Economic Geography, 79, 4.

Apel, H., Aronica, G. T., Kreibich, H., Thieken, A. H. (2009). Flood risk analyses - how detailed do we need to be? Natural Hazards, 49(1), 79-98.

Babcicky, P., Seebauer, S. (2017). The two faces of social capital in private flood mitigation: Opposing effects on risk perception, self-efficacy and coping capacity. Journal of Risk Research, 20(8), 1017-1037.

Babcicky, P., Seebauer, S. (2019a). Unpacking Protection Motivation Theory: evidence for a separate protective and non-protective route in private flood mitigation behavior. Journal of Risk Research,22(12), 15031521.

Babcicky, P., Seebauer, S. (2019b). Collective efficacy and natural hazards: Differing roles of social cohesion and task-specific efficacy in shaping risk and coping beliefs. Journal of Risk Research. doi:10.1080/13669877.2019.1628096.

Babcicky, P., Seebauer, S. (under review). The sources of belief in personal capability: Antecedents of selfefficacy in private adaptation to flood risk, Copy available upon request.

Baker, E. J. (1991). Hurricane evacuation behavior. International Journal of Mass Emergencies and Disasters, 9(2), 287-310.
Bateman, J. M., Edwards, B. (2002). Gender and evacuation: A closer look at why women are more likely to evacuate for hurricanes. Natural Hazards Review, 3(3), 107-117.

Beierlein, C., Kemper, C. J., Kovaleva, A., Rammstedt, B. (2012). Ein Messinstrument zur Erfassung politischer Kompetenz-und Einflussüberzeugungen: Political Efficacy Kurzskala (PEKS), GESIS-Working Papers, 2012/18, GESIS - Leibniz-Institut für Sozialwissenschaften, Mannheim.

Beierlein, C., Kovaleva, A., Kemper, C. J., Rammstedt, B. (2014). Eine Single-Item-Skala zur Erfassung von Risikobereitschaft: Die Kurzskala Risikobereitschaft-1 (R-1), GESIS-Working Papers, 2014/34, GESIS Leibniz-Institut für Sozialwissenschaften, Mannheim.

Birkmann, J. (2006). Indicators and criteria for measuring vulnerability: Theoretical bases and requirements. Measuring Vulnerability to Natural Hazards: Towards Disaster Resilient Societies, 55-77.

Birkmann, J., Cardona, O.D., Carreno, M.L., Barbat, A.H., Pelling, M., Schneiderbauer, S., Kienberger, S., Keiler, M., Alexander, D., Zeil, P., Welle, T. (2013): Framing vulnerability, risk and societal responses: The MOVE framework. Natural Hazards, 67, 193-211.

Botzen, W. J., Aerts, J. C., van den Bergh, J. C. (2009). Willingness of homeowners to mitigate climate risk through insurance. Ecological Economics, 68(8-9), 2265-2277.

Botzen, W. W., Kunreuther, H., Czajkowski, J., de Moel, H. (2019). Adoption of Individual Flood Damage Mitigation Measures in New York City: An Extension of Protection Motivation Theory. Risk Analysis, 39(10), 2143-2159.

Brouwer, R., Schaafsma, M. (2013). Modelling risk adaptation and mitigation behaviour under different climate change scenarios. Climatic Change, 117(1-2), 11-29.

Bubeck, P., Botzen, W. J., Aerts, J. C. (2012). A review of risk perceptions and other factors that influence flood mitigation behavior. Risk Analysis, 32(9), 1481-1495.

Bubeck, P., Botzen, W. J., Kreibich, H., Aerts, J. C. (2013). Detailed insights into the influence of floodcoping appraisals on mitigation behaviour. Global Environmental Change, 23(5), 1327-1338.

Bubeck, P., Wouter Botzen, W. J., Laudan, J., Aerts, J. C., Thieken, A. H. (2018). Insights into flood-coping appraisals of protection motivation theory: Empirical evidence from Germany and France. Risk Analysis, 38(6), 1239-1257.

Chakraborty, J., Tobin, G. A., Montz, B. E. (2005). Population evacuation: Assessing spatial variability in geophysical risk and social vulnerability to natural hazards. Natural Hazards Review, 6(1), 23-33.

Connor, K. M., Davidson, J. R. (2003). Development of a new resilience scale: The Connor-Davidson resilience scale (CD-RISC). Depression and Anxiety, 18(2), 7682.

Cutter, S. L., Boruff, B. J., Shirley, W. L. (2003). Social vulnerability to environmental hazards. Social Science Quarterly, 84(2), 242-261.

Doorn, N. (2017). Resilience indicators: Opportunities for including distributive justice concerns in disaster 
management. Journal of Risk Research, 20(6), 711731.

Fekete, A. (2009). Validation of a social vulnerability index in context to river-floods in Germany. Natural Hazards \& Earth System Sciences, 9(2).

Fekete, A. (2012). Spatial disaster vulnerability and risk assessments: Challenges in their quality and acceptance. Natural hazards, 61(3), 1161-1178.

Fekete, A. (2019). Social vulnerability (re-) assessment in context to natural hazards: Review of the usefulness of the spatial indicator approach and investigations of validation demands. International Journal of Disaster Risk Science, 10(2), 220-232.

Flanagan, B. E., Gregory, E. W., Hallisey, E. J., Heitgerd, J. L., Lewis, B. (2011). A social vulnerability index for disaster management. Journal of Homeland Security and Emergency Management, 8(1).

Fothergill, A. (1998). The neglect of gender in disaster work: An overview of the literature. The Gendered Terrain of Disaster: Through Women's Eyes. Westport, CT, Praeger Publishers. pp11-25.

Friborg, O., Barlaug, D., Martinussen, M., Rosenvinge, J. H., Hjemdal, O. (2005). Resilience in relation to personality and intelligence. International Journal of Methods in Psychiatric Research, 14(1), 29-42.

Fujikawa, M., Lee, E. J., Chan, F., Catalano, D., Hunter, C., Bengtson, K., Rahimi, M. (2013). The ConnorDavidson Resilience Scale as a positive psychology measure for people with spinal cord injuries. Rehabilitation Research, Policy, and Education, 27(3), 213-222.

Fuchs, S., Röthlisberger, V., Thaler, T., Zischg, A., Keiler, M. (2017). Natural hazard management from a coevolutionary perspective: Exposure and policy response in the European Alps. Annals of the American Association of Geographers, 107, 382-392.

Gan, X., Fernandez, I. C., Guo, J., Wilson, M., Zhao, Y., Zhou, B., Wu, J. (2017). When to use what: Methods for weighting and aggregating sustainability indicators. Ecological Indicators, 81, 491-502.

Gianisa, A., Le De, L. (2018). The role of religious beliefs and practices in disaster. Disaster Prevention and Management, 27(1), 74-86.

Gladwin, H., Peacock, W. G. (1997). Warning and evacuation: A night for hard houses. In: Peacock, et al. (Ed.), Hurricane Andrew: Ethnicity, Gender, and the Sociology of Disasters, Routledge, New York. pp5274.

Green, R., Bates, L. K., Smyth, A. (2007). Impediments to recovery in New Orleans' upper and lower ninth ward: One year after hurricane Katrina. Disasters, 31(4), 311-335.

Grothmann, T., Reusswig, F. (2006). People at risk of flooding: Why some residents take precautionary action while others do not. Natural Hazards, 38(1-2), 101-120.

Habersack, H. M., Bürgel, J., Petraschek, A. (2005). Analysis of the Flood Events in August 2002 FloodRisk. Bundesministerium für Land- und Forstwirtschaft, Umwelt und Wasserwirtschaft, Vienna.
Hübl, J., Beck, M. (2018). Ereignisdokumentation 2017 Detailberichte Salzburg und Steiermark. IAN Report 192. Bundesministerium für Nachhaltigkeit und Tourismus, Wildbach- und Lawienenverbauung, Vienna.

Hudson, P., Hagedoorn, L., Bubeck, P. (2020). Potential Linkages Between Social Capital, Flood Risk Perceptions, and Self-Efficacy. International Journal of Disaster Risk Science. doi: 10.1007/s13753-02000259-w.

IPCC (2014). Summary for policymakers. In: Climate Change 2014: Impacts, Adaptation, and Vulnerability. Part A: Global and Sectoral Aspects. Contribution of Working Group II to the Fifth Assessment Report of the Intergovernmental Panel on Climate Change [Field, C.B., V.R. Barros, D.J. Dokken, K.J. Mach, M.D. Mastrandrea, T.E. Bilir, M. Chatterjee, K.L. Ebi, Y.O. Estrada, R.C. Genova, B. Girma, E.S. Kissel, A.N. Levy, S. MacCracken, sLepP.R. Mastrandrea, and L.L. White (eds.)]. Cambridge University Press, Cambridge.

Jongman, B., Koks, E. E., Husby, T. G., Ward, P. J. (2014): Increasing flood exposure in the Netherlands: implications for risk financing. Natural Hazards and Earth System Sciences, 14, 1245-1255

Jonkman, S. N. (2007). Loss of life estimation in flood risk assessment: Theory and applications. Proefschrift, University of Technology, Delft.

Jonkman, S. N., Kelman, I. (2005). An analysis of the causes and circumstances of flood disaster deaths. Disasters, 29(1), 75-97.

Kaniasty, K., Norris, F. H. (1995). In search of altruistic community: Patterns of social support mobilization following Hurricane Hugo. American Journal of Community Psychology, 23(4), 447-477.

Karagiorgos, K., Thaler, T., Heiser, M., Hübl, J., Fuchs, S. (2016). Integrated flash flood vulnerability assessment: Insights from East Attica, Greece. Journal of Hydrology, 541, 553-562.

Kennedy, P. (2003). A Guide to Econometrics - 5th Edition, MIT Press, Cambridge.

Kienberger, S. (2012). Spatial modelling of social and economic vulnerability to floods at the district level in Búzi, Mozambique. Natural Hazards, 64(3), 20012019.

Kievik, M., Gutteling, J. M. (2011). Yes, we can: Motivate Dutch citizens to engage in self-protective behavior with regard to flood risks. Natural Hazards, 59(3), 1475.

Kind, J., Botzen, W. W., Aerts, J. C. (2020). Social vulnerability in cost-benefit analysis for flood risk management. Environment and Development Economics, 25(2), 115-134.

Kreibich, H., Christenberger, S., Schwarze, R. (2011). Economic motivation of households to undertake private precautionary measures against floods. Natural Hazards and Earth System Sciences, 11(2), 309.

Kuhlicke, C., Scolobig, A., Tapsell, S., Steinführer, A., De Marchi, B. (2011). Contextualizing social vulnerability: Findings from case studies across Europe. Natural Hazards, 58(2), 789-810. 
Kuhlicke, C., Seebauer, S., Hudson, P., Begg, C., Bubeck, P., Dittmer, C., Masson, T., Reiter, J., Thaler, T., Thieken, A. H., Bamberg, S. (2020). The behavioral turn in flood risk management, its assumptions and potential implications. Wiley Interdisciplinary Reviews: Water, e1418.

Laska, S. B. (1986). Involving homeowners in flood mitigation. Journal of the American Planning Association, 52(4), 452-466.

Laska, S., Morrow, B. H. (2006). Social vulnerabilities and Hurricane Katrina: An unnatural disaster in New Orleans. Marine Technology Society Journal, 40(4), 16-26.

Leong, K. J., Airriess, C. A., Li, W., Chen, A. C. C., Keith, V. M. (2007). Resilient history and the rebuilding of a community: The Vietnamese American community in New Orleans East. The Journal of American History, 94(3), 770-779.

Lindell, M. K., Perry, R. W. (2004). Communicating environmental risk in multi-ethnic communities, Sage Publications, Thousand Oaks.

Lindell, M. K., Lu, J. C., Prater, C. S. (2005). Household decision making and evacuation in response to Hurricane Lili. Natural Hazards Review, 6(4), 171179.

Lowe, D., Ebi, K. L., Forsberg, B. (2013). Factors increasing vulnerability to health effects before, during and after floods. International Journal of Environmental Research and Public Health, 10(12), 7015-7067.

Mason, V., Andrews, H., Upton, D. (2010). The psychological impact of exposure to floods. Psychology, health \& medicine, 15(1), 61-73.

Masozera, M., Bailey, M., Kerchner, C. (2007). Distribution of impacts of natural disasters across income groups: A case study of New Orleans. Ecological Economics, 63(2-3), 299-306.

McGuire, L. C., Ford, E. S., Okoro, C. A. (2007). Natural disasters and older US adults with disabilities: Implications for evacuation. Disasters, 31(1), 49-56.

McIvor, D., Paton, D. (2007). Preparing for natural hazards: Normative and attitudinal influences. Disaster Prevention and Management, 16(1), 79-88.

Merz, B., Kreibich, H., Schwarze, R., Thieken, A., (2010). Assessment of economic flood damage. Natural Hazards and Earth System Sciences, 10, 1697-1724.

Mileti D. S. (1999). Disasters by design: A reassessment of natural hazards in the United States. Joseph Henry Press, Washington, DC.

Misanya, D., Øyhus, A. O. (2014). How communities' perceptions of disasters influence disaster response: Managing landslides on Mount Elgon, Uganda. Disasters, 39(2), 389-405.

Morote, R., Hjemdal, O., Uribe, P. M., Corveleyn, J. (2017). Psychometric properties of the Resilience Scale for Adults (RSA) and its relationship with lifestress, anxiety and depression in a Hispanic LatinAmerican community sample. PLoS ONE, 12(11), e0187954.

Morrow, B. H. (1999). Identifying and mapping community vulnerability. Disasters, 23(1), 1-18.
O'Brien, K., Sygna, L., Haugen, J. E. (2004). Vulnerable or resilient? A multi-scale assessment of climate impacts and vulnerability in Norway. Climatic Change, 64(1-2), 193-225.

Papathoma-Köhle M., Kappes M., Keiler M., Glade T. (2011) Physical vulnerability assessment for alpine hazards: State of the art and future needs. Natural Hazards 58(2), 645-680

Parker, D. J., Priest, S. J., Tapsell, S. M. (2009). Understanding and enhancing the public's behavioural response to flood warning information. Meteorological Applications, 16(1), 103-114.

Paton, D. (2013). Disaster resilient communities: Developing and testing an all-hazards theory. IDRiM Journal, 3(1), 1-17.

Paul, S. K., Routray, J. K. (2011). Household response to cyclone and induced surge in coastal Bangladesh: Coping strategies and explanatory variables. Natural Hazards, 57(2), 477-499.

Pelling, M. (1998). Participation, social capital and vulnerability to urban flooding in Guyana. Journal of International Development: The Journal of the Development Studies Association, 10(4), 469-486.

Penning-Rowsell, E. C., Green, C. (2000). New insights into the appraisal of flood-alleviation benefits: (1) Flood damage and flood loss information. Water and Environment Journal, 14(5), 347-353.

Penning-Rowsell, E., Johnson, C., Tunstall, S., Tapsell, S., Morris, J., Chatterton, J., Green, C. (2005). The benefits of flood and coastal risk management: A handbook of assessment techniques. ISBN 1904750516.

Podsakoff, P. M., MacKenzie, S. B., Lee, J. Y., Podsakoff, N. P. (2003). Common method biases in behavioral research: A critical review of the literature and recommended remedies. Journal of Applied Psychology, 88(5), 879.

Poussin, J. K., Botzen, W. W., Aerts, J. C. (2014). Factors of influence on flood damage mitigation behaviour by households. Environmental Science \& Policy, 40, 6977.

Prettenthaler, F., Kortschak, D., Hochrainer-Stigler, S., Mechler, R., Urban, H., Steininger, K. (2015): Catastrophe Management: Riverine Flooding, Chapter 18, In: Steininger, K. et al. (Ed.), Economic Evaluation of Climate Change Impacts: Development of a CrossSectoral Framework and Results for Austria, Springer, Berlin.

Putnam, R. D., R. Leonardi, Nanetti, R. Y. (1993). Making Democracy Work: Civic Traditions in Modern Italy, Princeton University Press, Princeton.

Remo, J. W., Pinter, N., Mahgoub, M. (2016). Assessing Illinois's flood vulnerability using Hazus-MH. Natural Hazards, 81(1), 265-287.

Riad, J. K., Norris, F. H., Ruback, R. B. (1999). Predicting evacuation in two major disasters: Risk perception, social influence, and access to resources. Journal of Applied Social Psychology, 29(5), 918-934.

Rufat, S., Tate, E., Burton, C. G., Maroof, A. S. (2015). Social vulnerability to floods: Review of case studies and implications for measurement. International Journal of Disaster Risk Reduction, 14, 470-486. 
Saja, A. A., Teo, M., Goonetilleke, A., Ziyath, A. M. (2018). An inclusive and adaptive framework for measuring social resilience to disasters. International Journal of Disaster Risk Reduction, 28, 862-873.

Sakakibara, H., Kajitani, Y., Okada, N. (2004). Road network robustness for avoiding functional isolation in disasters. Journal of Transportation Engineering, 130(5), 560-567.

Salvati, P., Petrucci, O., Rossi, M., Bianchi, C., Pasqua, A. A., Guzzetti, F. (2018). Gender, age and circumstances analysis of flood and landslide fatalities in Italy. Science of the Total Environment, 610, 867-879.

El Gibari, S., Gómez, T., Ruiz, F. (2019). Building composite indicators using multicriteria methods: A review. Journal of Business Economics, 89(1), 1-24.

Seebauer, S., Babcicky, P. (2018). Trust and the communication of flood risks: Comparing the roles of local governments, volunteers in emergency services, and neighbours. Journal of Flood Risk Management, 11(3), 305-316.

Seebauer, S., Winkler, C. (2020). Should I stay or should I go? Factors in household decisions for or against relocation from a flood risk area. Global Environmental Change, 60, 102018.

Soane, E., Schubert, I., Challenor, P., Lunn, R., Narendran, S., Pollard, S. (2010). Flood perception and mitigation: The role of severity, agency, and experience in the purchase of flood protection, and the communication of flood information. Environment and Planning A, 42(12), 3023-3038.

Solín, L', Madajová, M. S., Michaleje, L. (2018). Vulnerability assessment of households and its possible reflection in flood risk management: The case of the upper Myjava basin, Slovakia. International Journal of Disaster Risk Reduction, 28, 640-652.

Tapsell, S. M., Penning-Rowsell, E. C., Tunstall, S. M., Wilson, T. L. (2002). Vulnerability to flooding: Health and social dimensions. Philosophical Transactions of the Royal Society of London. Series A: Mathematical, Physical and Engineering Sciences, 360(1796), 15111525.

Tapsell, S., McCarthy, S., Faulkner, H., Alexander, M., Steinführer, A., Kuhlicke, C., Brown, S., Walker, G., Pellizzoni, L., Scolobig, A., De Marchi, B., Bianchizza, C., Supramaniam, M., Kallis, G. (2010). Social vulnerability to natural hazards. State of the art report from CapHaz-Net's WP4, London.

Tate, E. (2012). Social vulnerability indices: A comparative assessment using uncertainty and sensitivity analysis. Natural Hazards, 63(2), 325-347.

Terpstra, T. (2011). Emotions, trust, and perceived risk: Affective and cognitive routes to flood preparedness behavior. Risk Analysis, 31(10), 1658-1675.

Thaler, T., Seebauer, S. (2019). Bottom-up citizen initiatives in natural hazard management: Why they appear and what they can do? Environmental Science \& Policy, 94, 101-111.

Tonmoy, F. N., El-Zein, A., Hinkel, J. (2014). Assessment of vulnerability to climate change using indicators: A meta-analysis of the literature. Wiley Interdisciplinary Reviews: Climate Change, 5(6), 775-792.
Tonmoy, F. N., El-Zein, A. (2018). Vulnerability to sea level rise: A novel local-scale indicator-based assessment methodology and application to eight beaches in Shoalhaven, Australia. Ecological Indicators, 85, 295-307.

Townshend, I., Awosoga, O., Kulig, J., Fan, H. (2015). Social cohesion and resilience across communities that have experienced a disaster. Natural Hazards, 76(2), 913-938.

Tseng, C. P., Penning-Rowsell, E. (2012). Micro-political and related barriers to stakeholder engagement in flood risk management, The Geographical Journal, 178(3), 253-269.

Van Valkengoed, A. M., Steg, L. (2019). Meta-analyses of factors motivating climate change adaptation behaviour. Nature Climate Change, 9(2), 158-163.

Van Zomeren, M., Saguy, T., Schellhaas, F. M. (2013). Believing in "making a difference" to collective efforts: Participative efficacy beliefs as a unique predictor of collective action. Group Processes \& Intergroup Relations, 16(5), 618-634.

Varnes D (1984) Landslide hazard zonation: A review of principles and practice. UNESCO, Paris

Velasquez, G., Tanhueco, R. (2005). Know risk. In: Proceedings of the United Nations World Conference on Disaster Reduction, Hyogo, Japan.

Walker, M., Whittle, R., Medd, W., Burningham, K., Moran-Ellis, J., Tapsell, S. (2012). 'It came up to here': learning from children's flood narratives. Children's Geographies, 10(2), 135-150.

Walker-Springett, K., Butler, C., Adger, W. N. (2017). Wellbeing in the aftermath of floods. Health \& Place, 43, 66-74.

Wedawatta, G., Ingirige, B., Proverbs, D. (2014). Small businesses and flood impacts: The case of the 2009 flood event in Cockermouth. Journal of Flood Risk Management, 7(1), 42-53.

Werg, J., Grothmann, T., Schmidt, P. (2013). Assessing social capacity and vulnerability of private households to natural hazards-integrating psychological and governance factors. Natural Hazards \& Earth System Sciences, 13(6).

Wisner, B., Blaikie, P., Cannon, T., and Davis, I. (2004). At Risk: Natural hazards, people's vulnerability and disasters, 2nd Edition, Routledge, London. 


\section{Appendix}

Table A1. Sample descriptives

\begin{tabular}{|c|c|c|c|c|c|c|c|c|c|c|c|c|c|c|c|c|}
\hline \multirow{2}{*}{ Municipality } & & \multirow{2}{*}{$\begin{array}{c}\text { Percentage } \\
\begin{array}{c}\text { of total } \\
\text { sample }\end{array}\end{array}$} & \multirow{2}{*}{$\begin{array}{c}\text { Gender } \\
\text { Female }\end{array}$} & \multicolumn{5}{|c|}{ Age (years) } & \multicolumn{6}{|c|}{ Monthly net household income $(€)$} & \multirow{2}{*}{$\begin{array}{c}\begin{array}{c}\text { Flood } \\
\text { experience }\end{array} \\
\text { Yes }\end{array}$} & \multirow{2}{*}{$\begin{array}{r}\begin{array}{r}\text { Risk } \\
\text { zone }\end{array} \\
\text { Yes }\end{array}$} \\
\hline & & & & $18-34$ & $35-49$ & $50-64$ & $65-79$ & $\geq 80$ & $\leq 1,300$ & $\begin{array}{r}1,301 \\
-1,900\end{array}$ & $\begin{array}{c}1,901 \\
-3,000\end{array}$ & $\begin{array}{c}3,001 \\
-4,700\end{array}$ & $\begin{array}{c}4,701 \\
-6,500\end{array}$ & $>6,500$ & & \\
\hline \multirow{2}{*}{ Gröbming } & SD & $14.7 \%$ & $38 \%$ & $34 \%$ & $29 \%$ & $22 \%$ & $13 \%$ & $3 \%$ & $9 \%$ & $13 \%$ & $44 \%$ & $16 \%$ & $12 \%$ & $7 \%$ & $14 \%$ & $20 \%$ \\
\hline & PD & n.a. & $53 \%$ & $25 \%$ & $27 \%$ & $25 \%$ & $17 \%$ & $6 \%$ & $13 \%$ & $13 \%$ & $26 \%$ & $28 \%$ & $13 \%$ & $8 \%$ & n.a. & n.a. \\
\hline \multirow{2}{*}{ Irdning-Donnersbachtal } & SD & $16.2 \%$ & $32 \%$ & $23 \%$ & $29 \%$ & $32 \%$ & $12 \%$ & $4 \%$ & $6 \%$ & $18 \%$ & $35 \%$ & $31 \%$ & $6 \%$ & $5 \%$ & $25 \%$ & $13 \%$ \\
\hline & PD & n.a. & $53 \%$ & $24 \%$ & $23 \%$ & $28 \%$ & $17 \%$ & $7 \%$ & $13 \%$ & $13 \%$ & $26 \%$ & $28 \%$ & $13 \%$ & $8 \%$ & n.a. & n.a. \\
\hline \multirow{2}{*}{ Öblarn } & SD & $10.1 \%$ & $41 \%$ & $26 \%$ & $33 \%$ & $29 \%$ & $10 \%$ & $2 \%$ & $7 \%$ & $13 \%$ & $33 \%$ & $35 \%$ & $6 \%$ & $6 \%$ & $28 \%$ & $24 \%$ \\
\hline & PD & n.a. & $51 \%$ & $24 \%$ & $26 \%$ & $26 \%$ & $18 \%$ & $7 \%$ & $13 \%$ & $13 \%$ & $26 \%$ & $28 \%$ & $13 \%$ & $8 \%$ & n.a. & n.a. \\
\hline \multirow{2}{*}{ Sölk } & SD & $4.7 \%$ & $42 \%$ & $26 \%$ & $12 \%$ & $44 \%$ & $14 \%$ & $4 \%$ & $11 \%$ & $22 \%$ & $41 \%$ & $19 \%$ & $8 \%$ & $0 \%$ & $50 \%$ & $41 \%$ \\
\hline & PD & n.a. & $48 \%$ & $23 \%$ & $22 \%$ & $30 \%$ & $18 \%$ & $7 \%$ & $13 \%$ & $13 \%$ & $26 \%$ & $28 \%$ & $13 \%$ & $8 \%$ & n.a. & n.a. \\
\hline \multirow{2}{*}{ Stainach-Pürgg } & SD & $8.3 \%$ & $44 \%$ & $19 \%$ & $28 \%$ & $18 \%$ & $30 \%$ & $5 \%$ & $8 \%$ & $24 \%$ & $39 \%$ & $23 \%$ & $2 \%$ & $5 \%$ & $14 \%$ & $18 \%$ \\
\hline & PD & n.a. & $53 \%$ & $22 \%$ & $23 \%$ & $28 \%$ & $20 \%$ & $8 \%$ & $13 \%$ & $13 \%$ & $26 \%$ & $28 \%$ & $13 \%$ & $8 \%$ & n.a. & n.a. \\
\hline \multirow{2}{*}{ Grünbach } & SD & $2.8 \%$ & $24 \%$ & $10 \%$ & $21 \%$ & $55 \%$ & $14 \%$ & $0 \%$ & $0 \%$ & $17 \%$ & $42 \%$ & $21 \%$ & $17 \%$ & $4 \%$ & $55 \%$ & $17 \%$ \\
\hline & PD & n.a. & $49 \%$ & $27 \%$ & $24 \%$ & $29 \%$ & $15 \%$ & $5 \%$ & $8 \%$ & $14 \%$ & $26 \%$ & $27 \%$ & $15 \%$ & $11 \%$ & n.a. & n.a. \\
\hline \multirow{2}{*}{ Gutau } & SD & $3.9 \%$ & $20 \%$ & $12 \%$ & $38 \%$ & $36 \%$ & $14 \%$ & $0 \%$ & $3 \%$ & $12 \%$ & $39 \%$ & $36 \%$ & $9 \%$ & $0 \%$ & $17 \%$ & $5 \%$ \\
\hline & PD & n.a. & $49 \%$ & $23 \%$ & $25 \%$ & $31 \%$ & $15 \%$ & $6 \%$ & $8 \%$ & $14 \%$ & $26 \%$ & $27 \%$ & $15 \%$ & $11 \%$ & n.a. & n.a. \\
\hline \multirow{2}{*}{ Leopoldschlag } & SD & $3.2 \%$ & $26 \%$ & $18 \%$ & $24 \%$ & $38 \%$ & $21 \%$ & $0 \%$ & $4 \%$ & $32 \%$ & $20 \%$ & $40 \%$ & $4 \%$ & $0 \%$ & $47 \%$ & $18 \%$ \\
\hline & PD & n.a. & $49 \%$ & $24 \%$ & $21 \%$ & $33 \%$ & $15 \%$ & $7 \%$ & $8 \%$ & $14 \%$ & $26 \%$ & $27 \%$ & $15 \%$ & $11 \%$ & n.a. & n.a. \\
\hline \multirow{2}{*}{ Pregarten } & SD & $15.0 \%$ & $27 \%$ & $16 \%$ & $24 \%$ & $33 \%$ & $23 \%$ & $4 \%$ & $6 \%$ & $14 \%$ & $41 \%$ & $25 \%$ & $8 \%$ & $6 \%$ & $19 \%$ & $8 \%$ \\
\hline & PD & n.a. & $51 \%$ & $26 \%$ & $25 \%$ & $28 \%$ & $16 \%$ & $6 \%$ & $8 \%$ & $14 \%$ & $26 \%$ & $27 \%$ & $15 \%$ & $11 \%$ & n.a. & n.a. \\
\hline \multirow{2}{*}{ Rainbach } & SD & $4.5 \%$ & $20 \%$ & $10 \%$ & $41 \%$ & $37 \%$ & $10 \%$ & $2 \%$ & $3 \%$ & $14 \%$ & $22 \%$ & $38 \%$ & $22 \%$ & $3 \%$ & $18 \%$ & $0 \%$ \\
\hline & PD & n.a. & $49 \%$ & $24 \%$ & $26 \%$ & $25 \%$ & $18 \%$ & $7 \%$ & $8 \%$ & $14 \%$ & $26 \%$ & $27 \%$ & $15 \%$ & $11 \%$ & n.a. & n.a. \\
\hline \multirow{2}{*}{ Schwertberg (Perg) } & SD & $14.1 \%$ & $37 \%$ & $26 \%$ & $24 \%$ & $32 \%$ & $16 \%$ & $2 \%$ & $3 \%$ & $12 \%$ & $33 \%$ & $31 \%$ & $14 \%$ & $8 \%$ & $55 \%$ & $43 \%$ \\
\hline & PD & n.a. & $51 \%$ & $25 \%$ & $24 \%$ & $27 \%$ & $17 \%$ & $6 \%$ & $8 \%$ & $14 \%$ & $26 \%$ & $27 \%$ & $15 \%$ & $11 \%$ & n.a. & n.a. \\
\hline \multirow{2}{*}{ Windhaag } & SD & $2.4 \%$ & $28 \%$ & $16 \%$ & $36 \%$ & $32 \%$ & $16 \%$ & $0 \%$ & $19 \%$ & $14 \%$ & $33 \%$ & $33 \%$ & $0 \%$ & $0 \%$ & $20 \%$ & $0 \%$ \\
\hline & PD & n.a. & $50 \%$ & $21 \%$ & $26 \%$ & $32 \%$ & $15 \%$ & $6 \%$ & $8 \%$ & $14 \%$ & $26 \%$ & $27 \%$ & $15 \%$ & $11 \%$ & n.a. & n.a. \\
\hline \multirow{2}{*}{ All regions } & SD & $100 \%$ & $33 \%$ & $22 \%$ & $28 \%$ & $31 \%$ & $16 \%$ & $3 \%$ & $6 \%$ & $16 \%$ & $36 \%$ & $28 \%$ & $9 \%$ & $5 \%$ & $28 \%$ & $19 \%$ \\
\hline & PD & n.a. & $51 \%$ & $24 \%$ & $24 \%$ & $28 \%$ & $17 \%$ & $6 \%$ & $10 \%$ & $13 \%$ & $26 \%$ & $28 \%$ & $14 \%$ & $10 \%$ & n.a. & n.a. \\
\hline
\end{tabular}

\section{Table A1. References}

Statistics Austria (2018). EU-SILC Community Statistics on Income and Living Conditions, Statistics Austria, Vienna.

Statistics Austria (2019). Population at the beginning of the year since 2002 (regional status of 2019), Statistics Austria, Vienna. 
Table A2. Item wordings and reliability statistics

\begin{tabular}{|c|c|c|c|}
\hline Factor & Item wording & Response scale & $\alpha$ \\
\hline \multicolumn{4}{|c|}{ Flood scenario-based measures } \\
\hline \multicolumn{4}{|c|}{$\begin{array}{l}\text { Please imagine the following flood event: Water and mud are slowly penetrating your building. In the ground floor, the water is about ankle-deep. } \\
\text { If you have lower floors such as a basement or a garage, these areas are also affected. }\end{array}$} \\
\hline $\begin{array}{l}\text { Perceived flood } \\
\text { probability }\end{array}$ & How likely do you consider such a situation to occur at your building? & $\begin{array}{l}\text { Five-step, } \\
5=\text { very likely }\end{array}$ & n.a. \\
\hline $\begin{array}{l}\text { Vulnerability outcomes: } \\
\text { immediate }\end{array}$ & $\begin{array}{l}\text { How severely would you be affected by the following impacts during such a flood and in the days after? } \\
\text { Building and contents damage (e.g. walls, wooden floors, door frames, furniture, home appliance, ...) } \\
\text { Loss of personal items (e.g. irreplaceable memorabilia, personal items, photos, ...) } \\
\text { Health impacts (e.g. exhaustion, injury, illness, ...) } \\
\text { Stress (e.g. move possessions to a safe place, improvised living situation, clean-up work, ...) }\end{array}$ & $\begin{array}{l}\text { Five-step, } \\
5=\text { very severely }\end{array}$ & n.a. \\
\hline $\begin{array}{l}\text { Vulnerability outcomes: } \\
\text { long-term }\end{array}$ & $\begin{array}{l}\text { How severely would you be affected by the following impacts in the weeks and months after such a flood? } \\
\text { Financial damage (e.g. used up savings, take out a loan, cut back on household expenses, ...) } \\
\text { Mental impacts (e.g. sleeping problems, helplessness, recurring memories, worries, ...) } \\
\text { Struggle to return to normal (e.g. tedious repairs, bureaucratic hurdles, cut back on vacations and leisure, ...) }\end{array}$ & $\begin{array}{l}\quad \text { Five-step, } \\
5=\text { very severely }\end{array}$ & n.a. \\
\hline \multicolumn{4}{|l|}{ General measures } \\
\hline Protection intention & $\begin{array}{l}\text { I am planing to improve my protection against flooding. } \\
\text { I intend to improve my flood protection through personal efforts. } \\
\text { I am planning to improve my flood protection by myself. }\end{array}$ & $\begin{array}{l}\text { Five-step, } \\
5=\text { fully agree }\end{array}$ & .80 \\
\hline Fear of flooding & $\begin{array}{l}\text { I am very worried about the potential threat of flooding. } \\
\text { I am afraid of a potential flood. }\end{array}$ & $\begin{array}{l}\text { Five-step, } \\
5=\text { fully agree }\end{array}$ & .79 \\
\hline Risk-taking & How willing are you in general to take risks? & $\begin{array}{l}\text { Seven-step, } \\
7=\text { very willing to take risk } \\
1=\text { not at all willing to take } \\
\text { risk }\end{array}$ & n.a. \\
\hline Social norms & $\begin{array}{l}\text { People who are close to me attempt to improve their flood protection. } \\
\text { My neighbours approve it that I care about my flood protection. } \\
\text { My friends value it when I improve my flood protection. }\end{array}$ & $\begin{array}{l}\text { Five-step, } \\
5=\text { fully agree }\end{array}$ & .66 \\
\hline Social capital & $\begin{array}{l}\text { Generally speaking, in my hometown, ... } \\
\text {... most people can be trusted / ... you can't be too careful when dealing with others } \\
\text {... most people try to be fair / ... most people take advantage of others if they get the chance } \\
\text {... people care for each other / ... people primarily consider their own needs } \\
\text {... many people are engaged in formal associations or churches / ... only a few people are engaged }\end{array}$ & $\begin{array}{l}2=\text { positive statement } / \\
-2=\text { negative statement }\end{array}$ & .79 \\
\hline Institutional capital & $\begin{array}{l}\text { Generally speaking, in my hometown, ... } \\
\text {... everybody may take part when important decisions are made / ... selected few decide over all others } \\
\text {... a compromise is pursued when important decisions are made / ... selected few push their own interests } \\
\ldots \text { people try to make the town a better place to live / ... people hardly bother about the town } \\
\ldots \text { politicians and authorities act in a fair way according to their best intentions / ... politicians and authorities } \\
\text { favour certain people }\end{array}$ & $\begin{array}{l}2=\text { positive statement } / \\
-2=\text { negative statement }\end{array}$ & .83 \\
\hline Self-efficacy & $\begin{array}{l}\text { I am able to take on activities regarding my flood protection, even if they are stressful and difficult. } \\
\text { I am capable of protecting myself from flooding. } \\
\text { I can count on my knowledge and skills, even if I am planning to implement difficult flood protection } \\
\text { measures. }\end{array}$ & $\begin{array}{l}\text { Five-step, } \\
5 \text { = fully agree }\end{array}$ & .60 \\
\hline $\begin{array}{l}\text { Collective efficacy: } \\
\text { internal }\end{array}$ & $\begin{array}{l}\text { I could greatly contribute to achieve a better flood protection together with my neighbours. } \\
\text { I could make a small but important contribution to improve our flood protection together with my } \\
\text { neighbours. }\end{array}$ & $\begin{array}{l}\text { Five-step, } \\
5 \text { = fully agree }\end{array}$ & .66 \\
\hline $\begin{array}{l}\text { Collective efficacy: } \\
\text { external }\end{array}$ & $\begin{array}{l}\text { Through collaboration with my neighbours, I could improve flood protection. } \\
\text { Through collective efforts together with my neighbours, I could achieve progress in flood protection. }\end{array}$ & $\begin{array}{l}\text { Five-step, } \\
5 \text { = fully agree }\end{array}$ & .67 \\
\hline $\begin{array}{l}\text { Political efficacy: } \\
\text { internal }\end{array}$ & $\begin{array}{l}\text { I have the confidence to take active part in a discussion about flood protection. } \\
\text { I am good at understanding and assessing important issues around flood protection. }\end{array}$ & $\begin{array}{c}\text { Five-step, } \\
5 \text { = fully agree }\end{array}$ & .55 \\
\hline $\begin{array}{l}\text { Political efficacy: } \\
\text { external }\end{array}$ & $\begin{array}{l}\text { Politicians care about what people think about flood protection. } \\
\text { Politicians strive to keep in close touch with the people with regard to flood protection. }\end{array}$ & $\begin{array}{l}\text { Five-step, } \\
5=\text { fully agree }\end{array}$ & .69 \\
\hline Wishful thinking & $\begin{array}{l}\text { The next flood will surely not occur as soon as currently expected. } \\
\text { The next flood will surely cause much less damage than is currently expected. }\end{array}$ & $\begin{array}{l}\text { Five-step, } \\
5 \text { = fully agree }\end{array}$ & .47 \\
\hline $\begin{array}{l}\text { Reliance on public } \\
\text { flood protection }\end{array}$ & $\begin{array}{l}\text { I can entirely rely on public protection in [name of municipality]. } \\
\text { I trust in good flood protection in [name of municipality]. } \\
\text { Public flood protection makes me feel safe. }\end{array}$ & $\begin{array}{c}\text { Five-step, } \\
5=\text { fully agree }\end{array}$ & .83 \\
\hline $\begin{array}{l}\text { Reliance on public } \\
\text { compensation }\end{array}$ & $\begin{array}{l}\text { After a flood event, most of my damage would be covered by insurance, public institutions or donations. } \\
\text { After a flood event, I would need to cover most of my damage by myself. } \\
\text { I am confident that insurance, public institutions or donations would cover most of my flood damage. }\end{array}$ & $\begin{array}{l}\text { Five-step, } \\
5 \text { = fully agree }\end{array}$ & .72 \\
\hline $\begin{array}{l}\text { Ascription of } \\
\text { responsibility }\end{array}$ & Who, in your opinion, is primarily responsible for flood protection? & $\begin{array}{l}\text { Five-step, } \\
5=\text { myself, } \\
3=\text { both, } \\
1 \text { = government }\end{array}$ & n.a. \\
\hline Structured style & $\begin{array}{l}\text { I keep up my daily routines even at difficult times. } \\
\text { Rules and regular routines make it easier for me to overcome crises. }\end{array}$ & $\begin{array}{c}\text { Five-step, } \\
5=\text { fully agree }\end{array}$ & .53 \\
\hline $\begin{array}{l}\text { Tolerance of negative } \\
\text { affect }\end{array}$ & $\begin{array}{l}\text { Under pressure, I focus and think clearly. } \\
\text { I can handle unpleasant feelings. }\end{array}$ & $\begin{array}{c}\text { Five-step, } \\
5=\text { fully agree }\end{array}$ & .54 \\
\hline Spiritual influences & $\begin{array}{l}\text { Things happen for a reason. } \\
\text { Sometimes fate or God can help. }\end{array}$ & $\begin{array}{c}\text { Five-step, } \\
5=\text { fully agree }\end{array}$ & .39 \\
\hline
\end{tabular}

